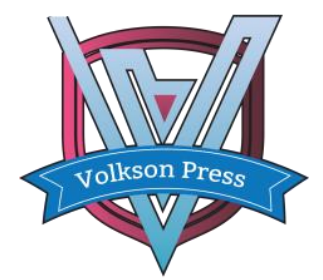

Contents List available at VOLKSON PRESS

Economics \& Management Innovations(EMI)

DOI : http://doi.org/10.26480/icemi.01.2017.30.32

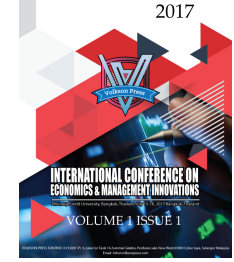

\title{
Coping Methods of Bankruptcy Law on Zombie Enterprises in the Background of Structural Reform of Supply-Side
}

\author{
Zhang Zhongqiang ${ }^{1}{ }^{*}$, Shen Laijin ${ }^{2}$ \\ School of Humanities and Law, Wuhan University of Technology, Wuhan, P.R.China, 430070
}

*email: 350581373@qq.com,1106548263@qq.com

This is an open access article distributed under the Creative Commons Attribution License, which permits unrestricted use, distribution, and reproduction in any medium, provided the original work is properly cited.

\section{ARTICLE DETAILS}

\section{Article History:}

Received 02 october 2017

Accepted 06 october 2017

Available online 11 october 2017

Keywords:

Supply-side; Zombie enterprises; Restructure; Bankruptcy.

\section{ABSTRACT}

It is an important task to promote the structural reform of supply-side by properly disposing of the zombie enterprises, making full use of the principles of marketization and legalization. Among the effective methods to the disposal of the zombie enterprises, the one of legalization taking the bankruptcy law as the core, is the most powerful weapon. First of all, by using the methods of literature analysis and empirical research, this paper puts forward the identification method, cause of formation, harm and the necessity of proper disposal of the zombie enterprises. Considering the problems that exist in China's bankruptcy reorganization system, the paper then puts forward three pieces of suggestion to perfect the current bankruptcy law, the first is to create more channels to resolve the bankruptcy case's "initial start difficulty", the second is to improve the bankruptcy proceedings, the third is to establish the supporting system of the bankruptcy system, in order to provide the guarantee mechanism for purging zombie enterprises by way of marketization and legalization under the background of the structural reform of supply-side.

\section{Introduction}

On 26 January, 2016, in the twelfth meeting of the Central Financial Leading Group, General Secretary Xi Jinping stated that "On the basis of moderate expansion of aggregate demand, we shall focus on fostering the structural reform of supply-side and improving the quality and efficiency of supplying system, to enhance the sustainable economic growth." [1] In recent years, affected by the international environment and the adjustment of economic structure, the China's economy lacks sustainable motivation, and GDP growth also has slowed down. Some scholars pointed out that the deep-seated causes of economic imbalances under the New Normal, lie in structural imbalance in the economy, in other words, the changes of effective supply and market demand are not consistent, and structural overcapacity is serious, which leads to the phenomenon of zombie enterprises quite serious.[2] The proper dispose of zombie enterprises, is not only the inevitable requirement to resolve excess capacity, but also an important starting point for the structural reform of supply-side. At present, there are many theories about supply-side reforms in China, but there are few research results on the coping methods, in particular ones of using bankruptcy law, about zombie enterprises under the background of structural reforms of the supply-side. It should be said that the effective reply for zombie enterprises and the effective utilization of bankruptcy law have been neglected. There are also relevant research results of bankruptcy law at abroad, and some scholars have introduced the practice of foreign countries, but we shall learn from the experience of the west in stead of copying only.

\section{The Zombie Enterprises : Definition and Identification}

The zombie enterprise is an economic term put forward by economist Peter Koi, referring to those who do not want to recover, but escape the bankruptcy due to the support of the lender or the government.[3] In 1980 s, in the United States, due to the free development of the aviation industry, a large number of zombie enterprises appeared. The outbreak of the financial crisis in 2008 caused the phenomenon of zombie enterprises to extend to the United States in the real estate industry, the automotive industry and other industries. In 1990s, Japan also suffered from zombie enterprises problems, there were zombie enterprises occupying a large amount of social resources, resulting in "crowding out effect" upon outstanding enterprises, "reverse elimination" phenomenon, and eventually leading to asset bubbles burst, and the recession "lost ten years" economic phenomenon.[4] The understanding of zombie enterprises in China can be dated back to the early 1990s, when the state-owned enterprises were in the operating difficulties, as well as the plight of SMEs in Wenzhou at the beginning of the 20th century. Some scholars have proposed that the so-called zombie enterprise refers to the one who has discontinued, or semi discontinued, or lost successively, or been in insolvency, and maintained the operation mainly by government subsidies and bank loans.[5]

\section{The Cause and Hazards of Zombie Enterprises}

In China, there are reasons for the formation of the zombies enterprises and the difficulty to purging them to reduce the adverse the rate of loans and avoid carrying credit risk considerations. First of all, in the background of the system of tax distribution, due to the competition between the local governments, different governments will choose to vigorously support the enterprises involved in the areas of key industries of the country and the new industries, and then the companies tend to expand blindly causing the overcapacity. Secondly, due to the adjustment of industrial structure, some enterprises in the industries with high energy consumption and high pollution, depending on the long-term extensive mode of development with element input and scale expansion, have caused the industry overcapacity and the heavy stockpile of goods with low technology content and low added value. When the enterprises are difficult to transform and upgrade, they will fall into the predicament of management, high debt and become zombie enterprises. Finally, subject to the operation and evaluation mechanism, and considering its own interests, the bank will continue to provide financial support for zombie enterprises. The disposal and write-off the bad assets have a great impact on the bank's profit growth, while profit growth is often regarded as one of the important criteria of bank assessment. Under such a mechanism, in view of reducing the adverse the rate of loans and avoiding carrying credit risk, the bank will continue to provide loans for the zombie enterprises to refinance and repay the interest by borrowing the capital, to avoid bankruptcy. Zombie enterprises occupy a large amount of labor, land, capital and other important resources, reduce or inhibit the allocation and efficiency of resources, which seriously hinders the most active factor in the productivity of labor. Meanwhile, they will inhibit innovation and bring 
the "crowding out effect" to new industries, which are on behalf of the advanced productive forces and high-quality industry, and have seriously hindered the effect of the survival of the fittest market. The existence of zombie enterprises also seriously damaged the fair and orderly market competition environment. Because the zombie enterprises will attain the "special treatment" from the government, banks and other departments, their product price is often lower than the market average, resulting in unfair competition and the situation that "Bad money drives out good". Zombie enterprises occupy the quality resources of bank credit in the long run, which causes the bank's nonperforming assets rate increase and may lead to systemic financial risk.

\section{Coping Methods of Bankruptcy Law on Zombie Enterprises}

From the experience on the disposal of zombie enterprises, accurate screening of zombie enterprises, taking timely and appropriate measures, alleviating the conflict of administrative intervention and market mechanism, ad balancing the relationship between social stability and reform are important factors in the successful disposal of zombie enterprises.[6] And when taking timely and appropriate response measures, the key lies in the provision of market-oriented system of supply, and bankruptcy system, as the core of the withdrawal system of the main body of the market, is crucial for the elimination of zombie enterprises.

\subsection{Multi-channel to Resolve "Initial Start Difficulty" in Bankruptcy Cases}

For the enterprises representing backward production capacity, with few business prospects, little relief and hope, and no market competitiveness, we must resolutely use the powerful weapon of bankruptcy law. But viewing from the experience of disposing zombie enterprises using the bankruptcy law, bankruptcy cases are often faced with "initial start difficulty".[7] There are many

reasons: First, subject to the shackles of traditional ideas, the enthusiasm initiative of the debtor is not high when filing for bankruptcy liquidation. In the bankruptcy law of China, for the start of bankruptcy procedure, the court can only advise and aufklaerung, while the parties apply for doctrine. Thus, there is no mandatory start of bankruptcy procedure for the court, which causes many cases not to enter the bankruptcy procedure timely and effectively, resulting that the number of bankruptcy cases increase instead. Secondly, the local government's intervention. As previously mentioned, because the bankruptcy and liquidation of zombie enterprises will involve the placement of workers, social stability and other issues, the bankruptcy liquidation of large central enterprises or state-owned enterprises tend to suffer from the local government obstruction.

Therefore, the government should actively encourage and vigorously guide the related parties to establish a strong positive understanding of the bankruptcy reorganization system, vigorously promote the successful case of bankruptcy reorganization, and establish the individual bankruptcy exemption system for those in charge of the enterprises, to distinguish their management responsibilities from the irresistible force. The government shall encourage the administrators in enterprise to solve the enterprise's debt problem through the bankruptcy judicial means, to eliminate the fear, concerns and obstacles that they will bear responsibility because of bankruptcy. Secondly, the court should actively exercise the right of aufklarungsrecht, by advising and promoting bankruptcy benefits for the parties, to encourage the enterprises in compliance with the standard of bankruptcy enter bankruptcy liquidation procedures.

\subsection{Improve the System, Simplify the Procedure, to Ensure the} Effective Bankruptcy Reorganization

First of all, to improve the existing bankruptcy administrator selection and accountable system. The provisions of the bankruptcy administrator in China's current bankruptcy law are too abstract and principled, facing many realistic problems in the implementation process, and they are mainly directly specified by the court, causing the will of the creditors difficult to achieve. Therefore, it is necessary to add effective, standardized bankruptcy administrator specific selection mechanism to the current legislation, making the selection specific and systematic, making full use of the market principle, giving consideration to multistakeholders needs, and selecting bankruptcy administrators with ability and high efficiency. Moreover, improve the accountability system afterwards, to force the bankruptcy administrator operate in order in the process of bankruptcy liquidation to prevent the transfer of benefits, and to ensure fair and impartial bankruptcy liquidation. Secondly, to establish the specialized bankruptcy court, we shall set up simple bankruptcy proceedings. Based on specialization and complexity of bankruptcy cases, and in view of the current problems of courts in the trial of bankruptcy cases, we shall set up a professional court of bankruptcy, and form bankruptcy trial system as soon as possible, in order to improve the quality and the efficiency of the bankruptcy case. In order to solve the problem of long cycle, the court should actively explore and establish simple proceedings in the case of bankruptcy, compress the trial period, make research on matters within the existing legal framework which can be combined, and establish "easy access" for the bankruptcy case, to make the trial of bankruptcy cases "fast and excellent" come true.[8]

\subsection{Repair the Mechanism, Place Properly, to Ensure the Effect of Bankruptcy Reorganization}

Banks should improve their own credit system and establish a credit repairing mechanism. In many cases on the reorganization of the enterprises, due to the same name and organization code of the enterprise after reforming, the enterprise's credit records still existed, which made the enterprise very difficult to obtain funds from the bank loan support after the reorganization. Therefore, banks and other financial departments should establish a credit repairing mechanism of enterprise reorganization, and remove bad credit records of the enterprise before the reorganization timely.

The government should handle issues of the zombie companies resettlement. In the process of bankruptcy reorganization of the enterprise, all information should be adhere to the principles of openness and transparency, to avoid serious social problems caused by large-scale layoffs, and actively guide the employment or entrepreneurship. Protect the interests of employees and establish unemployment through the establishment of re-employment training and job placement system. And the government shall set up special fund on employees of the bankrupt enterprise security for the realization of their basic wage, unemployment placement and social insurance.

\section{Conclusion}

In the current social-economic background, it is necessary to reform the current bankruptcy law, and introduce the market-oriented system, to give full play to the role of the bankruptcy reorganization system in the adjustment of economic structure. China is currently in the key stage of leveraging, digesting excess capacity and adjusting the economic structure, thus, in the process of disposal of zombie enterprises, we shall change the past administrative means, choose means of the market to effectively deal with the plight of the enterprise instead, making the market play a key role in the redistribution of resources. In this process, the bankruptcy law plays a very important role. Therefore, the process of rule of law need to be vigorously promoted for the process of zombie enterprises governance. We shall improve the existing bankruptcy law, and make full use of the three procedures, reorganization, reconciliation, and liquidation, adding to the establishment of supporting system for bankruptcy, to bring protection for purging the zombie enterprises in the rule of law, and promote the structural reform of supply-side finally.

\section{References}

[1] Nie Huihua, Jiangting, Zhang Yuxiao, Fang Mingyue: The Paper on the Research of China ZomEnterprises-Tatus, Cause, and Solutions[M]. Beijing: China Social Science Press(2016)

[2] Hu Wenfeng: Simple Explanation on Purging Zombie Enterprises[J]. Law \& Society.(2016).

[3] Hefan, Zhuhe: Identification and Coping of Zombie Enterprises[J]. China Finance.(2016). [4] Wu Jinrong: Discussion on Issues in Law in the Disposal of Zombie Enterprises[J]. Rule of Law.(2016).

[5] Liu Aijuan: Discussion on the Problems of Zombie Enterprises[J]. Consumer Guide(2016). [6] Zhao Shuwen, Wang Jiawei: Research on the Protection of the Rule of Law in the Disposal of

Zombie Enterprises-the Improvement of Bankruptcy Law and Its Implementation Mechanism as the Research Path[J]. Hebei Law Science(2017).

[7] Zhang Yanli: Problems and Solutions of the Effective Operation for the Bankruptcy Reorganization System[J]. Law Review(2016). 

Court[J]. Law \& Economy(2016). 